\title{
Inhibin secretion by the sheep ovary
}

\author{
J. K. Findlay, C. G. Tsonis $\ddagger$ L. D. Staples* and R. N. P. Cahill $\dagger$ \\ Medical Research Centre, Prince Henry's Hospital, Melbourne, Victoria 3004; *Animal Research \\ Institute, Werribee, Victoria 3030; and $\dagger$ School of Veterinary Science, University of Melbourne, \\ Parkville, Victoria 3052, Australia
}

\begin{abstract}
Summary. An in-vitro bioassay for inhibin based on FSH content or release by rat pituitary cells was validated for measuring inhibin activity in ovine plasma and lymph. Dose-dependent increases in inhibin activity were detected in peripheral plasma of 4 ovariectomized ewes $1 \mathrm{~min}$ after i.v. injections of ovine follicular fluid, and the half-life of inhibin in plasma for 2 ewes was 45 and $50 \mathrm{~min}$, respectively.

Inhibin was detected in ovarian lymph but not in ovarian or jugular venous plasma, even after treatment of ewes with PMSG to induce folliculogenesis. Destruction of visible follicles ( $>0.5 \mathrm{~mm}$ diameter) on the ovaries of 4 PMSG-treated ewes by electrocautery was followed by a rapid and sustained decline in secretion of inhibin in ovarian lymph for up to $4 \mathrm{~h}$. Ovarian lymph flow rates were either unchanged or slightly increased after cautery. Oestrogen concentrations in peripheral venous plasma declined within 15-30 min of cautery, but concentrations remained well above baseline. There was a significant decrease in peripheral progesterone concentrations in these same samples, but not until 2-3 h after cautery. FSH in peripheral plasma was depressed or non-detectable in PMSG-treated ewes and neither FSH nor LH concentrations in peripheral plasma were significantly altered up to $4 \mathrm{~h}$ after cautery of ovarian follicles.

It is concluded that (a) antral follicles $(>0.5 \mathrm{~mm}$ ) are the source of inhibin present in ovarian lymph, and (b) the ovarian lymphatic system is a route by which inhibin could reach the peripheral circulation, particularly in the luteal phase when ovarian lymph flow rates are high.
\end{abstract}

\section{Introduction}

Inhibin is a gonadal peptide which selectively suppresses the secretion of FSH by the pituitary gland (de Jong, 1979; Robertson et al., 1985). It is synthesized by the granulosa cells of the ovarian follicle (Erickson \& Hsueh, 1978; Henderson \& Franchimont, 1981) and accumulates in the follicular fluid of all mammalian species examined, including sheep (Tsonis et al., 1983). If inhibin has physiological relevance by acting at the level of the pituitary to control FSH secretion, it must reach the pituitary via the peripheral circulation. Inhibin activity has been measured in peripheral blood of PMSG-treated immature rats (Lee, McMaster, Quigg, Findlay \& Leversha, 1981) and prooestrous rats (Lee, Hulse \& Leversha, 1983a) by well characterized in-vitro bioassays (Scott, Burger \& Quigg, 1980; Lee, Quigg, McMaster, Burger \& Leversha, 1983b). Lee, McMaster, Quigg \& Leversha (1982) calculated the half-life of inhibin in peripheral plasma of rats to be of the order of $30 \mathrm{~min}$. To reach the peripheral circulation, inhibin could be released from ovarian follicles into the ovarian venous system, the ovarian lymphatics or both.

$\ddagger$ Present address: Department of Obstetrics and Gynaecology, University of Edinburgh, Centre for Reproductive Biology, 37 Chalmers Street, Edinburgh, EH3 9EW, U.K. 
FSH-suppressing activity has been measured in ovarian venous plasma of pro-oestrous rats (de Paola, Shander, Wise, Barraclough \& Channing, 1979; Shander, Anderson \& Barraclough, 1980; Anderson \& Hoover, 1982) and monkeys (Channing, Anderson \& Hodgen, 1980), but the data are largely based on single point assays and not on potencies derived from dose-response curves compared to a standard reference preparation. Redmer, Christenson, Ford, Day \& Goodman (1984) reported inhibin activity in the ovarian vein of gilts before and after unilateral ovariectomy. Baker, Eddie, Higginson, Hudson \& Niall (1982) were unable to measure inhibin activity in testicular venous blood of rams, but were able to show that the daily output of inhibin in testicular lymph approximated that in rete testis fluid. There are no reports to date on inhibin activity in ovarian lymph.

The aim of this study was to measure inhibin activity in peripheral and ovarian venous plasma and ovarian lymph of ewes, some of which were treated with PMSG to enhance folliculogenesis and hence inhibin production. The half-life of exogenous inhibin in peripheral plasma of ewes was also examined.

\section{Materials and Methods}

\section{Animals and experimental design}

The ovarian lymphatics of 2 Merino (Exp. 1) and 6 Corriedale ewes (Exp. 3) were cannulated according to the methods of Morris \& McIntosh (1971) and Staples, Fleet \& Heap (1982), while a prescapular lymphatic was also cannulated in the 2 Merino ewes, using a technique similar to that described by Lascelles \& Morris (1961).

In Exp. 1, ovarian and prescapular lymph was collected in plastic tubes containing 100 units of heparin (CSL, Melbourne, Victoria, Australia) in $0.1 \mathrm{ml}$, from 2 conscious ewes every $3 \mathrm{~h}$ for as long as the cannulae remained patent. One ewe received $125 \mu \mathrm{g}$ cloprostenol (ICI, Melbourne, Victoria, Australia) on Day 15 to ensure that luteolysis took place. The ewes were on Days 9 and 14 of the cycle, respectively (Day $0=$ day of oestrus). The volume of lymph was recorded, then the sample was centrifuged $(1500 \mathrm{~g}$ for $15 \mathrm{~min})$ and the supernatant stored at $-15^{\circ} \mathrm{C}$ until assayed for inhibin.

In Exp. 2, 4 ovariectomized Merino ewes had both jugular veins cannulated, one for injecting charcoal-treated ovine follicular fluid with inhibin activity and the other for blood sampling. Animals received doses of $10000,20000,40000$ or $80000 \mathrm{U}$ inhibin, respectively, as a bolus injection made up to a $10 \mathrm{ml}$ volume with $0.9 \%(\mathrm{w} / \mathrm{v}) \mathrm{NaCl}$. A blood sample was taken immediately before the bolus injection $\left(t_{0}\right)$ and thereafter at $1,2 \cdot 5,5,10,20,30,60,120,360,720$ and $1140 \mathrm{~min}$. Blood was collected into heparinized syringes and then centrifuged at $1500 \mathrm{~g}$ for $15 \mathrm{~min}$. The plasma was stored at $-15^{\circ} \mathrm{C}$ until assayed for inhibin.

In Exp. 3, 6 Corriedale ewes were given 1500 i.u. PMSG (Folligon: Intervet, Sydney, NSW, Australia) on Day 7 of the oestrous cycle to induce follicle growth. On Day 9, anaesthesia was induced in each ewe with pentobarbitone sodium (Park Davis, Sydney, NSW, Australia) and maintained with $1 \%$ halothane (ICI) for the duration of the experiment $(5-6 \mathrm{~h})$. The reproductive tract was exposed at midventral laparotomy and a major ovarian lymph duct draining the ovary with one or more corpora lutea was cannulated as described above. The ovarian vein was also cannulated, as described by McNatty, Gibb, Dobson, Thurley \& Findlay (1981), and a cannula was placed in one jugular vein. The size distribution of ovarian follicles $>0.5 \mathrm{~mm}(<2,2-4$ and $>4 \mathrm{~mm}$, to the nearest $0.5 \mathrm{~mm}$, measured by comparing with spheres of known diameter) and the number and distribution of corpora lutea on each ovary were recorded (Table 1). Ovarian lymph, accumulated in plastic tubes as described above, and ovarian and jugular venous blood samples collected by syringe, were obtained every $15 \mathrm{~min}$ for $3-3.5 \mathrm{~h}$, and then every $30 \mathrm{~min}$ for a further $2 \mathrm{~h}$. The volume of each ovarian lymph sample was recorded. At $2 \mathrm{~h}$ after the start of sampling, all 
follicles visible at the ovarian surface were ablated by electrocautery. In the first 2 ewes, the contralateral ovary was also removed at this time, with the aim of determining the contribution of the remaining ovary to peripheral inhibin concentrations and also the peripheral ovarian venous differences in inhibin concentration. This was not done in the subsequent animals after preliminary analyses had revealed that inhibin concentration was below detection in ovarian and peripheral venous plasma. Blood samples were centrifuged and the plasmas and the corresponding lymph samples were stored at $-15^{\circ} \mathrm{C}$ until assayed for hormone content.

\section{Hormone assays}

Inhibin. Lymph and plasma samples were assayed for inhibin using the in-vitro bioassays based on the cell (Scott et al., 1980) or medium (Lee et al., 1983b; Tsonis, 1984) content of FSH. Plasma and lymph samples were treated with dextran-coated charcoal at a final concentration of $1 \mathrm{mg} / \mathrm{ml}$ and assayed at 2-3 dilutions in triplicate using up to $25 \mu \mathrm{l}$ per well. Potencies were calculated by parallel line bioassay statistics (Finney, 1964) and are expressed in terms of a standard, ovine rete testis fluid (ORTF), which has a potency of $1 \mathrm{U} / \mathrm{mg}$ (Eddie, Baker, Higginson \& Hudson, 1979).

FSH. FSH concentrations in jugular venous plasma were measured by radioimmunosassay (Bremner, Findlay, Lee, de Kretser \& Cumming, 1980) using NIH-FSH-13 as standard. All samples were measured at $300 \mu \mathrm{l}$ in one assay in which the intra-assay coefficient of variation (CV) was $<15 \%$ between 1.7 and $330 \mathrm{ng} / \mathrm{ml}$; maximum precision was $4.1 \%$. The characteristics of this and other radioimmunoassays were calculated by the method of Burger, Lee \& Rennie (1972).

$L H$. Concentrations of $\mathrm{LH}$ in jugular venous plasma were measured by radioimmunoassay (Lee et al., 1976) using NIH-LH-S18 as standard. All samples were measured at $300 \mu \mathrm{l}$ in one assay in which the within-assay $\mathrm{CV}$ was $<15 \%$ between 0.3 and $15 \mathrm{ng} / \mathrm{ml}$; maximum precision was $4 \cdot 1 \%$.

Steroids. The concentrations of progesterone in peripheral and ovarian venous plasma were measured by radioimmunoassay using reagents supplied by the WHO Matched Radioimmunoassay Reagent Program. Total oestrogens were measured by radioimmunoassay according to the method of Carson, Salamonsen \& Findlay (1986). The progesterone assay is specific, whereas the oestrogen assay detects oestradiol $-17 \beta$ and oestrone equally, therefore values are expressed as total oestrogens. Samples of ovarian venous plasma $(50-100 \mu \mathrm{l}$; recovery $72 \%)$ and peripheral plasma $(1 \mathrm{ml}$; recovery $46 \%$ ) were extracted with diethyl ether before assay in duplicate for total oestrogens. For progesterone, ovarian venous plasma $(10 \mu \mathrm{l})$ was assayed without extraction, whereas peripheral plasma $(1 \mathrm{ml}$; recovery $51 \%$ ) was extracted with diethyl ether before assay. The reagent blanks were below the sensitivities of the respective assays (progesterone, $17 \cdot 4 \pm 4.3$ (4) fmol/tube; oestrogen $1.86 \pm 0.35(5) \mathrm{fmol} /$ tube; mean \pm s.e.m. $(n))$. For progesterone, the within-assay $\mathrm{CV}$ was $<15 \%$ between 25 and $1000 \mathrm{fmol} /$ tube with a mean maximum precision of $5 \cdot 2 \pm 2 \cdot 1 \%$. The between-assay $\mathrm{CV}$ was $8 \cdot 2 \%$. For oestrogen, with within-assay CV was $<15 \%$ between 6 and $200 \mathrm{fmol} /$ tube with a mean maximum precision of $6 \cdot 7 \pm 0 \cdot 8 \%$. The between-assay CV was $10 \cdot 4 \%$.

\section{Data analysis}

Ovarian lymph flow and hormone concentrations before and after cautery of ovarian follicles in Exp. 3 were compared by independent $t$ test. Inhibin secretion $(\mathrm{U} / \mathrm{h})$ in lymph was derived from the inhibin concentration $(\mathrm{U} / \mathrm{ml})$ and the rate of lymph flow $(\mathrm{ml} / \mathrm{h})$.

\section{Results}

Characterization of inhibin bioassays for ovine plasma and lymph

Different doses up to $25 \mu \mathrm{l}$ per well of plasma from the ewe which received $80000 \mathrm{U}$ inhibin (Exp. 2), prescapula lymph to which ORTF had been added (Fig. 1) and ovarian lymph.from 


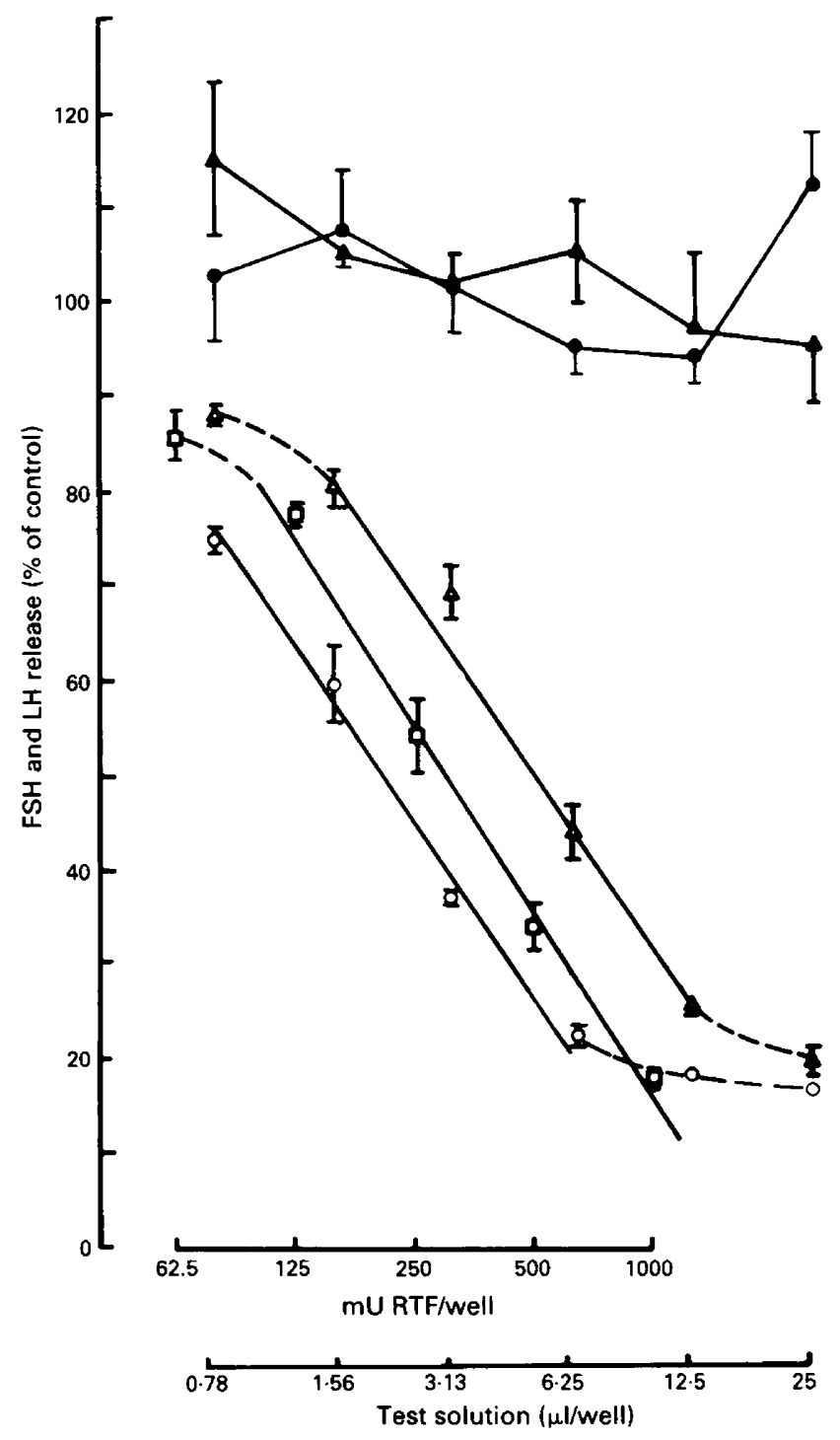

Fig. 1. The effect of various doses of peripheral plasma $(\Delta \boldsymbol{\Delta})$ from an ovariectomized ewe given $80000 \mathrm{U}$ inhibin i.v., ovine prescapula lymph $(\mathrm{O})$ to which the inhibin standard, ORTF (1U/mg), has been added, and the ORTF standard $(\square)$ on the release of FSH $(\triangle O \square)$ and $\mathrm{LH}(\Delta \boldsymbol{\Lambda})$ by rat anterior pituitary cells in vitro. Values are mean \pm s.e.m. of quadruplicate determinations.

PMSG-treated ewes (Exp. 3) each resulted in a specific, dose-related suppression of FSH release from the rat pituitary cells, parallel to the inhibin standard. Inhibin activity was not detected $(<4 \mathrm{U} / \mathrm{ml})$ in plasma taken at $t_{0}$ from ovariectomized ewes (Fig. 2) or in most samples of prescapula lymph (Fig. 3). Some prescapula lymph samples to which ORTF had not been added had very low activity at the highest dose but further dilutions did not give a dose-response. The concentrations of inhibin in 5 ovarian lymph samples measured in the cell content and media release assays were not different $(t=1 \cdot 58 ; P>0.05$, paired $t$ test). The media release assay was much less 
variable than the cell content assay, judging by the indices of precision $(\lambda, 0.09 v s 0.17)$ and Finney's g values $(0.003$ vs 0.066$)$.

\section{Measurement of inhibin in plasma and lymph (Exps 1\&2)}

In Exp. 1, inhibin concentrations in ovarian lymph from the 2 ewes ranged from 4 to $180 \mathrm{U} / \mathrm{ml}$ (data not shown) in contrast to prescapula lymph, which was below detection. The inhibin secretion in ovarian lymph was variable but increased in both ewes (Fig. 3) during the time of expected follicle growth in the preovulatory period.

In Exp. 2, the inhibin activity measured in plasma samples taken $1 \mathrm{~min}$ after a bolus injection of ovine follicular fluid was related to the dose given to each ovariectomized ewe (Fig. 2). Only the data from ewes receiving 40000 and $80000 \mathrm{U}$ inhibin were used to calculate the half-life of inhibin in peripheral plasma because it was not possible to obtain parallel dose-response lines with samples from the 2 ewes that received lower doses, with the exception of samples taken at $1 \mathrm{~min}$. The pattern of appearance and disappearance of inhibin in plasma of the 2 ewes that received the higher doses were similar. Maximum concentrations were observed at $1 \mathrm{~min}$, and thereafter the concentrations plateaued until $20 \mathrm{~min}$ after which there was a linear decay in activity with time (Fig. 2). The half-life values were 45 and $50 \mathrm{~min}$, respectively.
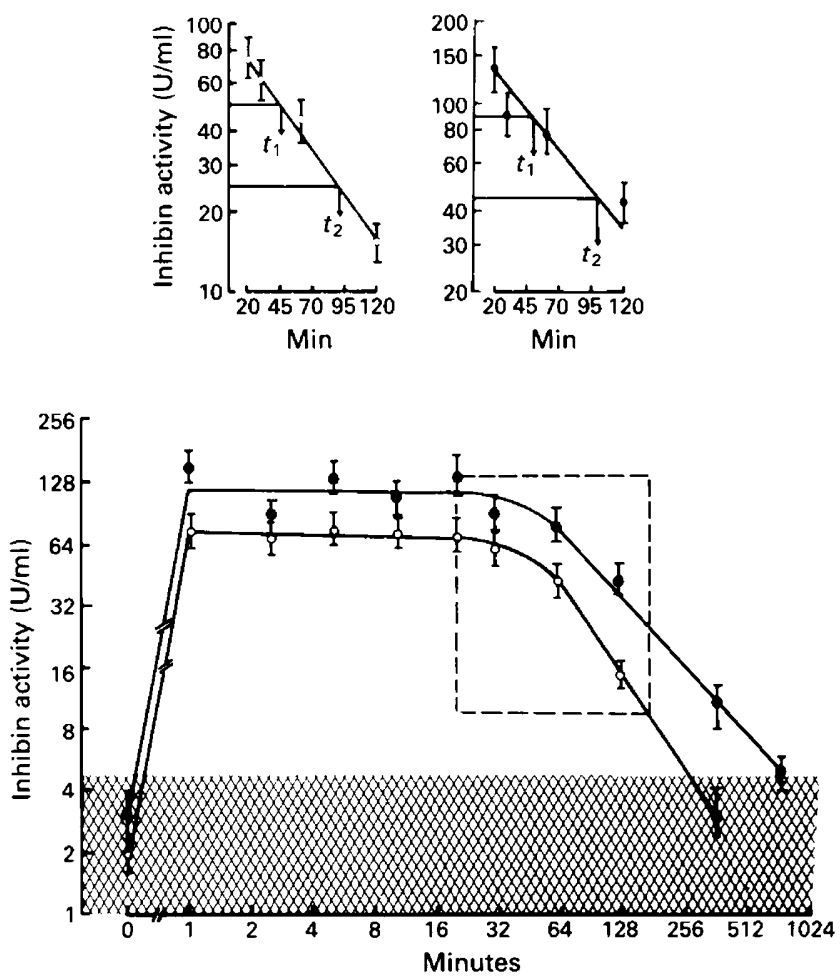

Fig. 2. The concentrations of inhibin in peripheral plasma of 2 ovariectomized ewes which received charcoal-treated ovine follicular fluid containing $40000(\mathrm{O})$ and $80000(\odot) \mathrm{U}$ of inhibin by i.v. injection at $t_{0}$. The shaded area is below detection in the inhibin bioassay. Values are mean $\pm 95 \%$ confidence intervals. The half-life of inhibin was calculated at the time of exponential decay from the plots shown above the main figure. 


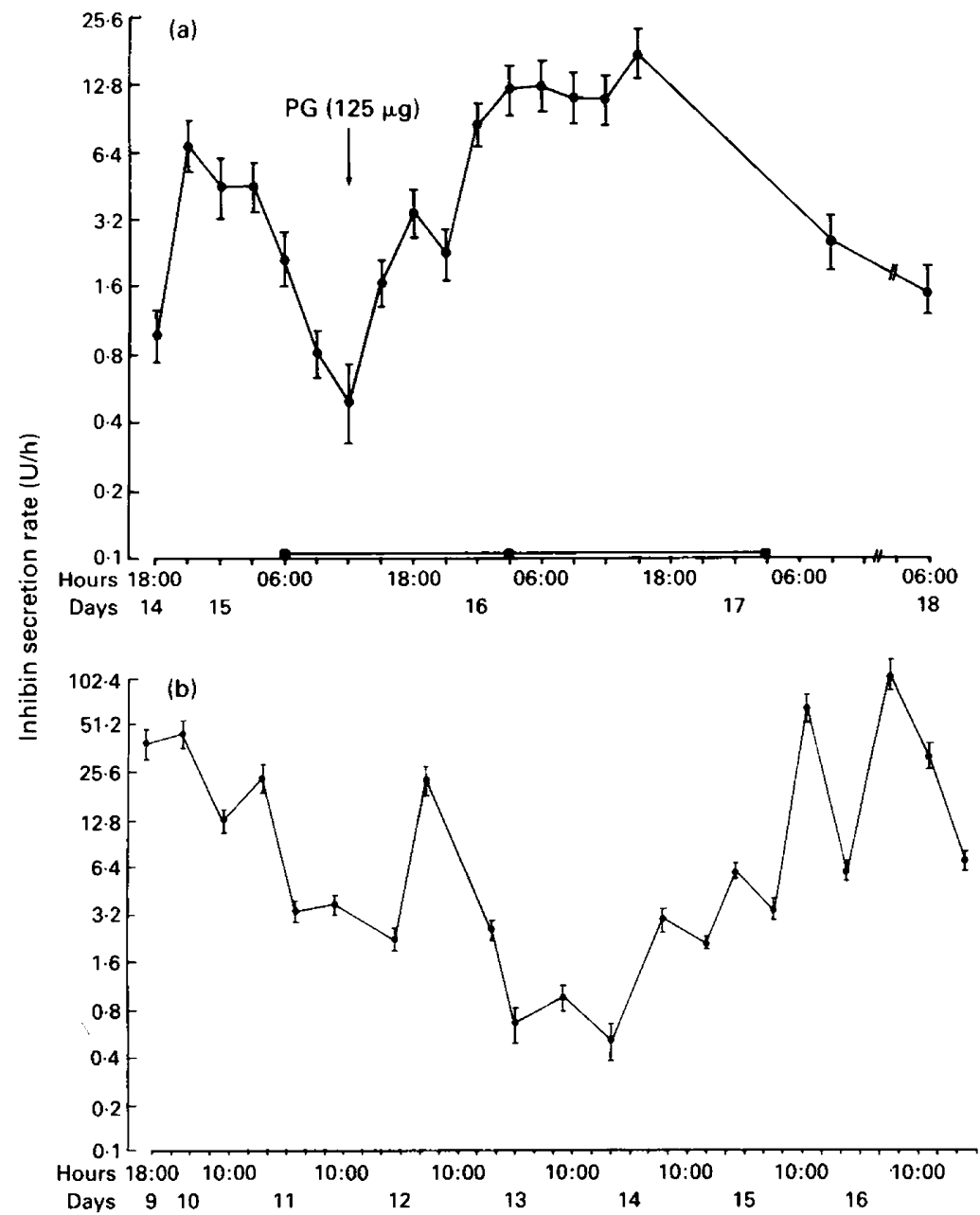

Fig. 3. The secretion rate of inhibin in the lymph ducts of 2 ewes $(a, b)$ during the late luteal-early follicular phase of the cycle. (a) Ovarian (O) and prescapula (ם) samples were obtained from this ewe which received $125 \mu \mathrm{g}$ cloprostenol to induce luteolysis. (b) Ovarian samples only were taken from this ewe. Values are mean $\pm 95 \%$ confidence intervals.

\section{Cautery of follicles and secretion of inhibin and steroids by the ovary (Exp. 3)}

Two ewes (Nos 9 and 75) had ovulated before cannulation, but all ewes had evidence of folliculogenesis (Table 1).

The mean flow rates of lymph were either unaltered ( 3 ewes) or significantly increased ( 2 ewes) after cautery (Table 2). Examination of flow rates in individual ewes (Fig. 4) revealed reasonably steady values for all ewes except No. 19, during the collection period, at least until $3 \mathrm{~h}$ after cautery (Table 2; Fig. 4).

The secretion rate of inhibin in ovarian lymph before cautery was high and variable (Fig. 4; Table 2). Inhibin in all lymph samples in Ewe 75 were below detection $(<2.5 \mathrm{U} / \mathrm{h})$, and in Ewe 120 there were too few samples to assay. Within 15-30 min of cautery, there was a rapid fall in inhibin secretion in lymph in 4 ewes (Fig. 4; Table 2), such that levels were either very low (2.5-10 U/h) or 
Table 1. Distribution of follicles visible on the ovarian surface and corpora lutea $48 \mathrm{~h}$ after giving PMSG to ewes on Day 7 of the oestrous cycle (Exp. 3)

\begin{tabular}{ccccccc}
\hline \multirow{2}{*}{$\begin{array}{c}\text { Ewe } \\
\text { no. }\end{array}$} & Ovary & $<2 \mathrm{~mm}$ & $2-4 \mathrm{~mm}$ & $>4 \mathrm{~mm}$ & $\begin{array}{c}\text { Corpora } \\
\text { lutea }\end{array}$ & $\begin{array}{c}\text { Fresh } \\
\text { ovulations }\end{array}$ \\
\cline { 3 - 6 } 9 & ${ }^{*} \mathrm{~L}$ & 0 & 3 & 2 & 2 & 1 \\
& $\dagger \mathrm{R}$ & $\mathrm{NR}$ & $\mathrm{NR}$ & $\mathrm{NR}$ & 0 & 2 \\
7 & $* \mathrm{~L}$ & 5 & 5 & 1 & 1 & 0 \\
& $+\mathrm{R}$ & 4 & 2 & 0 & 0 & 0 \\
3 & $* \mathrm{~L}$ & 1 & 1 & 1 & 1 & 0 \\
& $\mathrm{R}$ & 0 & 1 & 1 & 0 & 0 \\
19 & $* \mathrm{~L}$ & 0 & 0 & 10 & 1 & 0 \\
120 & $\mathrm{R}$ & 0 & 0 & 7 & 1 & 0 \\
& $\mathrm{~L}$ & 2 & 9 & 0 & 0 & 0 \\
75 & ${ }^{*} \mathrm{R}$ & 0 & 4 & 1 & 2 & 0 \\
& $* \mathrm{~L}$ & 3 & 0 & 1 & 1 & 1 \\
\hline
\end{tabular}

* Side of cannulation.

† Ovary removed before cautery.

NR, not recorded.
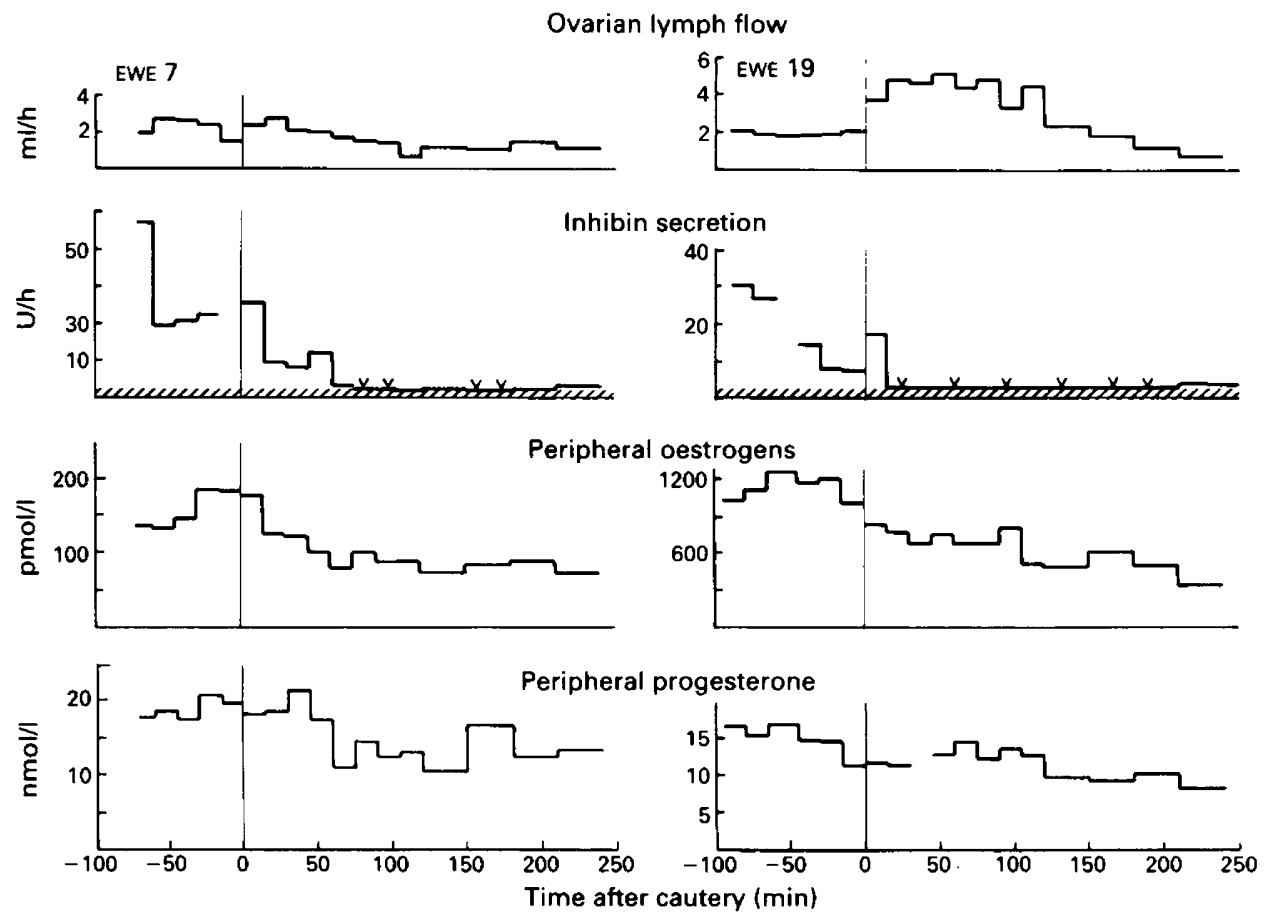

Fig. 4. The effect of removing visible antral follicles $(>0.5 \mathrm{~mm}$ diameter) by electrocautery on ovarian lymph flow, inhibin secretion rate in ovarian lymph, and peripheral concentrations of total oestrogen and progesterone in 2 PMSG-treated ewes on Day 9 of the cycle. The shaded area represents the level of detection of the inhibin bioassay. One ewe (No. 7) had the contralateral ovary removed at the time of cautery. 
$J$. K. Findlay et al.

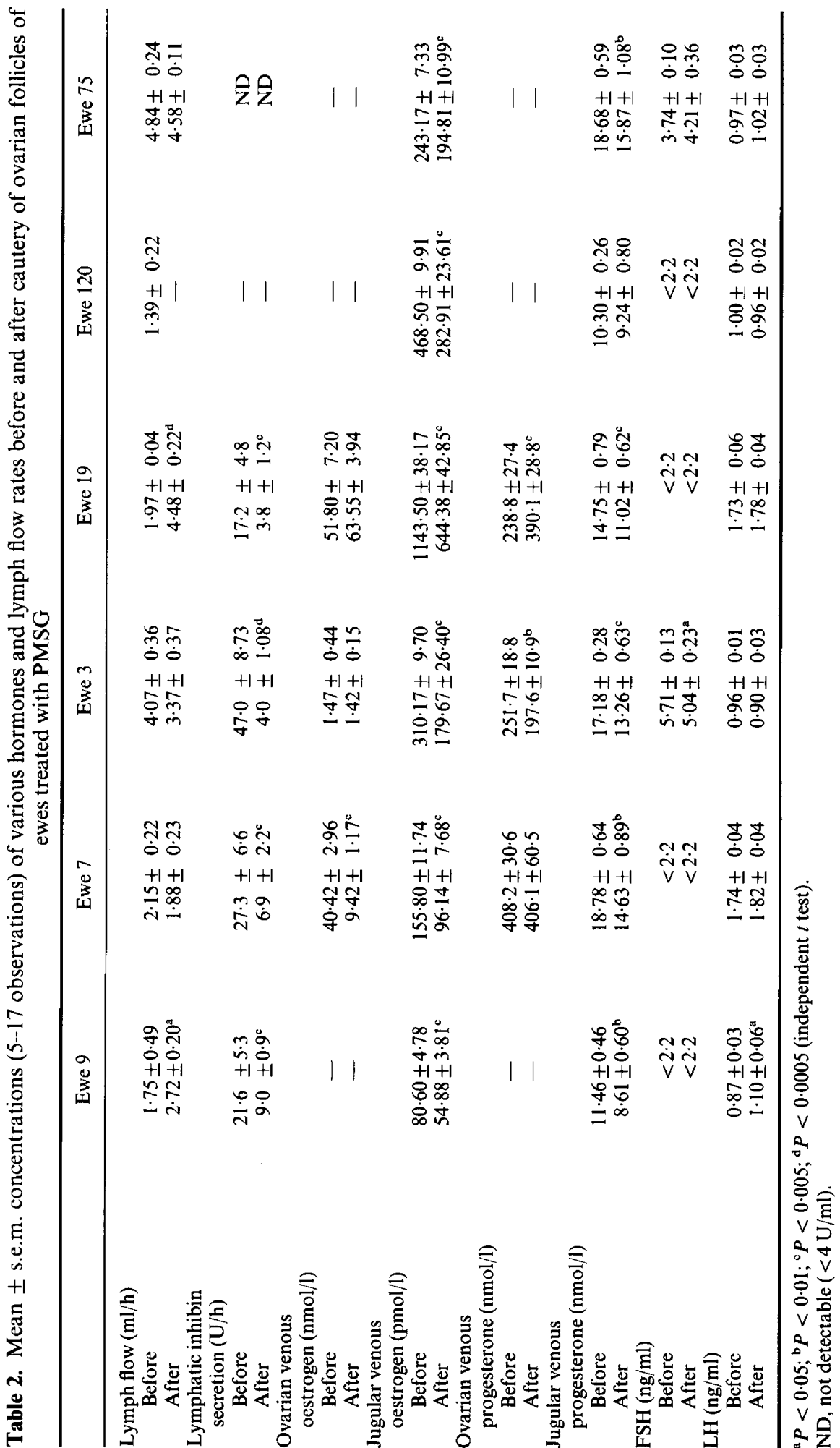


undetectable $(<2.5 \mathrm{U} / \mathrm{h})$ for the remaining period of observation. Inhibin was below the level of detection $(<4 \mathrm{U} / \mathrm{ml})$ in samples of ovarian and 2 samples of jugular venous plasma collected from Ewes 3 and 9 before cautery.

The concentrations of total oestrogen in peripheral (6/6 ewes) and ovarian venous plasma (1/3 ewes) decreased significantly $(P<0.05)$ within $15-30 \mathrm{~min}$ after cautery of follicles, but not to the same extent as the fall of inhibin in lymph (Table 2; Fig. 4). (There was insufficient lymph sample to measure steroids as well as inhibin.) Progesterone concentrations in peripheral plasma (5/6 ewes) decreased slightly but significantly $(P<0.05)$ after cautery, whereas the changes were variable in ovarian venous plasma of the 3 ewes in which it was measured (Table 2). The change in peripheral concentrations of progesterone was not apparent until 2-3 h after cautery.

FSH was below detection $(<2 \cdot 2 \mathrm{ng} / \mathrm{ml})$ in jugular venous plasma of 4 ewes, and in the remaining 2 ewes (Nos 3 and 75$)$ the concentrations were low $(2 \cdot 2-7 \cdot 5 \mathrm{ng} / \mathrm{ml})$ and there was a small but significant $(P<0.05)$ decrease after cautery in Ewe 3. LH concentrations were detected in samples from all ewes and found not to vary significantly $(P>0.05)$ before and after cautery, except in Ewe 9 , in which there was a small increase.

\section{Discussion}

Higher concentrations of inhibin activity were demonstrated in ovarian lymph than in prescapula lymph of ewes. These concentrations decreased to non-detectable levels after cautery of follicles on the ovary, supporting the hypothesis that large antral follicles are the major source of inhibin (Tsonis et al., 1983), which can reach the peripheral circulation via the ovarian lymphatics.

The failure to detect inhibin bioactivity in ovarian and venous plasma, even after treatment of ewes with PMSG was surprising, but it is similar to observations of rams (Baker et al., 1982) in which inhibin was detected in testicular lymph, but was undetectable in testicular venous plasma. However, venous outflow from the gonads (e.g. ovarian venous flow $=10 \mathrm{ml} / \mathrm{min}$; McNatty et al., $1981)$ is many times greater than lymph flow $(\sim 5 \mathrm{ml} / \mathrm{h}$ : Table 2$)$, so relatively small amounts of inhibin in venous plasma can make a major contribution to peripheral concentrations. The extent to which inhibin in ovarian lymph contributes to peripheral levels cannot be properly ascertained until it can be measured in ovarian venous and peripheral plasma. The total secretion rate of inhibin by the ovary into lymph is underestimated in this study because only one of several ducts draining one ovary were cannulated. It would be expected that inhibin secretion in lymph would be greater in the luteal than in the follicular phase of the oestrous cycle, because lymph flow is higher in the luteal than in the follicular phase (Morris \& Sass, 1966). Based on data in Table 2, there would be a total secretion rate of inhibin of about $100 \mathrm{U} / \mathrm{h}$ by two luteal-phase ovaries (or $2400 \mathrm{U} /$ day), which is approaching the doses of inhibin activity required to suppress FSH in ovariectomized ewes (Cummins, O'Shea, Bindon, Lee \& Findlay, 1983; Tsonis, 1984). Therefore, the ovarian lymphatics could be a significant route of secretion of inhibin from the ovary during the luteal phase of the ewe.

The 45-50 min half-life of exogenous ovine inhibin in the peripheral circulation of ovariectomized ewes compares well with a half-life of $30 \mathrm{~min}$ in plasma of PMSG treated immature rats, immediately after ovariectomy (Lee et al., 1982). This observed half-life $(45-50 \mathrm{~min})$ and the plateau in inhibin concentrations have been confirmed in 6 intact ewes (C. G. Tsonis, A. S. McNeilly \& D. T. Baird, unpublished observations). The reasons for the apparent plateau in inhibin concentrations for 30 min after i.v. injection are not known. There may be an equilibration within a body pool which might involve a binding or carrier protein, or dissociation of bound or polymeric forms of inhibin present in follicular fluid.

The reduction in peripheral concentrations of total oestrogens after cautery was expected because the antral follicles are the ovarian site of oestrogen production in sheep (McNatty et al., 1981; Tsonis, 1984). The capacity of the small follicles (up to $0.5 \mathrm{~mm}$ ) remaining after cautery 
to secrete significant amounts of oestrogen, but not inhibin, is illustrated by the oestrogen concentrations in ovarian and peripheral plasmas of Ewes 9 and 7 which had had one ovary removed. In 2 ewes (Nos 3 and 19), the decrease in peripheral concentrations of oestrogen was not matched by a decrease in ovarian venous concentrations. It is unlikely that large $(>0.5 \mathrm{~mm}$ diam.) follicles remained after cautery because inhibin concentrations decreased in the ovarian lymph of these ewes. The concentrations of oestrogen in ovarian venous plasma of Ewe 3 were low compared to those in the other ewes, suggesting that very few follicles remained after cautery and/or that they were atretic. A decrease in ovarian blood flow as a result of the anaesthesia and surgical procedures could result in similar or increased concentrations of steroid in ovarian venous plasma, as shown for ovarian venous progesterone in Ewe 19, but an overall decrease in ovarian steroid secretion rates. This could partly explain the decrease in peripheral concentrations of progesterone and oestrogen. However, an examination of the time course of these changes in peripheral steroid concentrations revealed that oestrogen concentrations fell within 15-30 min of cautery, whereas the decreases in progesterone were not apparent until 2-3 $\mathrm{h}$ after cautery. We conclude, therefore, that the decrease in peripheral oestrogen (and inhibin in ovarian lymph) was due to cautery of antral follicles, whereas the decrease in peripheral progesterone more likely resulted from a fall in ovarian blood flow and an inhibition of LH pulse frequency by the anaesthetics (Clarke \& Doughton, 1983).

The low or non-detectable concentrations of FSH and basal concentrations of LH in the PMSG treated ewes are indirect evidence for increased endogenous concentrations of inhibin, albeit below detection in the inhibin bioassay. Lee et al. $(1981,1982)$ observed similar effects on FSH in PMSG-treated immature rats. The lack of any significant change in concentrations of either gonadotrophin within 3-4 h of removing large follicles and, in 2 ewes, the contralateral ovary as well, was expected. FSH concentrations in peripheral plasma undergo a transient increase 5-12 h after unilateral ovariectomy (Findlay \& Cumming, 1977) and do not increase until at least $24 \mathrm{~h}$ after bilateral ovariectomy (McNeilly, 1980).

It is concluded that antral follicles $(>0.5 \mathrm{~mm}$ diam.) are the source of inhibin in ovarian lymph, and that, during the luteal phase of the sheep oestrous cycle, the ovarian lymphatic system is a route by which a significant proportion of inhibin could reach the peripheral circulation.

We thank Paul Weston and Linda Cavanagh for help with the surgery; Marzi de Garis, Emily Kolliniatis, Dr Ron Carson and Trevor Gill for help with hormone assays; Helen Quigg and Dr Victor Lee for help with the inhibin assays; Professor Henry Burger for helpful comments; and Diane Hollingsworth for preparation of the manuscript. The study was supported by grants from the Australian Meat Research Committee (AMRC) and the National Health and Medical Research Council of Australia. C.G.T. was a postgraduate scholar of the AMRC.

\section{References}

Anderson, L.D. \& Hoover, D.J. (1982) Hormonal control of inhibin secretion. Adv. exp. Med. Biol. 147, 53-59.

Baker, H.W.G., Eddie, L.W., Higginson, R.E., Hudson, B. \& Niall, H.D. (1982) Clinical context, neuroendocrine relationships and nature of inhibin in males and females. In Clinical Neuroendocrinology, Vol. 2, pp. 283-330. Eds G. M. Besser \& L. Martini. Academic Press, New York.

Bremner, W.J., Findlay, J.K., Lee, V.W.K., de Kretser, D.M. \& Cumming, I.A. (1980) Feedback effects of the testis on pituitary responsiveness to $\mathrm{LH}-\mathrm{RH}$ infusions in the ram. Endocrinology 106, 329-336.

Burger, H.G., Lee, V.W.K. \& Rennie, G.C. (1972) A generalised computer program for the treatment of data from competitive binding assays including radioimmunoassays. J. Lab. Clin. Med. 80, 302-312.

Carson, R.S., Salamonsen, L.A. \& Findlay, J.K. (1986) Permeability of rat ovarian follicles to LH during development and luteinization. J. Reprod. Fert. (in press).

Channing, C.P., Anderson, L. \& Hodgen, G.D. (1980) A search for inhibin activity in monkey ovarian vein blood (OVB) and follicular fluid (FFI). Proc. 6th Int. Congr. Endocr., Melbourne, Abstr. 178.

Clarke, I.J. \& Doughton, B.W. (1983) Effect of various anaesthetics on resting plasma concentrations of 
luteinizing hormone, follicle-stimulating hormone and prolactin in ovariectomized ewes. $J$. Endocr. 98, 79-89.

Cummins, L.J., O'Shea, T., Bindon, B.M., Lee, V.W.K. \& Findlay, J.K. (1983) Ovarian inhibin content and sensitivity to inhibin in Booroola and control strain Merino ewes. J. Reprod. Fert. 67, 1-7.

de Jong, F. H. (1979) Inhibin-fact or artefact. Molec. cell. Endocr. 13, 1-10.

de Paolo, L.V., Shander, P., Wise, P.M., Barraclough, C.A. \& Channing, C.P. (1979) Identification of inhibin-like activity in ovarian venous plasma of rats during the estrous cycle. Endocrinology 105, 647-654.

Eddie, L.W., Baker, H.W.G., Higginson, R.E. \& Hudson, B. (1979) A bioassay for inhibin using pituitary cell cultures. J. Endocr. 81, 49-60.

Erickson, G.F. \& Hsueh, A.J.W. (1978) Secretion of inhibin by rat granulosa cells in vitro. Endocrinology 103, 1960-1963.

Findlay, J.K. \& Cumming, I.A. (1977) The effect of unilateral ovariectomy on plasma gonadotropin levels, estrus and ovulation rate in sheep. Biol. Reprod. 17, 178-183.

Finney, D.J. (1964) Statistical Method in Biological Assay, 2nd edn. Charles Griffin, London.

Henderson, K.M. \& Franchimont, P. (1981) Regulation of inhibin production by bovine ovarian cells. $J$. Reprod. Fert. 63, 431-442.

Lascelles, A.K. \& Morris, B. (1961) Surgical techniques for the collection of lymph from unanaesthetized sheep. Q. Jl exp. Physiol. 46, 199-205.

Lee, V.W.K., Cumming, I.A., de Kretser, D.M., Findlay, J.K., Hudson, B. \& Keogh, E.J. (1976) Regulation of gonadotrophin secretion in rams from birth to sexual maturity. J. Reprod. Fert. 46, 1-6.

Lee, V.W.K., McMaster, J., Quigg, H., Findlay, J.K. \& Leversha, L. (1981) Ovarian and peripheral blood inhibin concentrations increase with gonadotropin treatment in immature rats. Endocrinology 108, 2403-2405.

Lee, V.W.K., McMaster, J., Quigg, H. \& Leversha, L. (1982) Ovarian and circulating inhibin levels in immature female rats treated with gonadotropin and after castration. Endocrinology 111, 1849-1854.

Lee, V.W.K., Hulse, G.K. \& Leversha, L. (1983a) Ovarian and circulating levels of inhibin in the rat oestrous cycle. Proc. Aust. Soc. Reprod. Biol. 15, Abstr. 77.

Lee, V.W.K., Quigg, H., McMaster, J., Burger, H.G. \& Leversha, L. (1983b) A sensitive and rapid bioassay for inhibin based on inhibition of pituitary gonadotrophin secretion in vitro. Proc. Endocr. Soc. Aust., Abstr. 32.

McNatty, K.P., Gibb, M., Dobson, C., Thurley, D.C. \& Findlay, J.K. (1981) Changes in the concentrations of gonadotrophic and steroidal hormones in the antral fluid of ovarian follicles throughout the oestrous cycle of the sheep. Aust. J. biol. Sci. 34, 67-80.

McNeilly, A.S. (1980) Prolactin and the control of gonadotrophin secretion in the female. J. Reprod. Fert. 58, 537-549.

Morris, B. \& Sass, M.B. (1966) The formation of lymph in the ovary. Proc. R. Soc. Lond. B 164, 577-591.

Morris, B. \& McIntosh, G.H. (1971) Techniques for the collection of lymph with special reference to the testis and ovary. Acta endocr., Copenh., Suppl. 158, 145-168.

Redmer, D.A., Christenson, R.K., Ford, J.J., Day, B.N. \& Goodman, A.L. (1984) Increased inhibin-like activity in ovarian venous serum after unilateral ovariectomy in prepubertal gilts. Biol. Reprod. 30, Suppl. 1, 147, Abstr. 233.

Robertson, D.M., Foulds, L.M., Leversha, L., Morgan, F.J., Hearn, M.T.W., Burger, H.G., Wettenhall, R.E.H. \& de Kretser, D.M. (1985) Isolation of inhibin from bovine follicular fluid. Biochem. Biophys. Res. Commun. 126, 220-226.

Scott, R.S., Burger, H.G. \& Quigg, H. (1980) A simple and rapid in vitro assay for inhibin. Endocrinology 107, 1536-1542.

Shander, P., Anderson, L.D. \& Barraclough, C.A. (1980) Follicle-stimulating hormone and luteinizing hormone affect the endogenous release of pituitary follicle-stimulating hormone and the ovarian release of inhibin in rats. Endocrinology 106, 1047-1053.

Staples, L.D., Fleet, I.R. \& Heap, R.B. (1982) Anatomy of the utero-ovarian lymphatic network and the composition of afferent lymph in relation to the establishment of pregnancy in the sheep and goat. $J$. Reprod. Fert. 64, 409-420.

Tsonis, C.G. (1984) Control of oestrogen and inhibin production during growth and atresia of the sheep ovarian follicle. Ph.D. thesis, Monash University.

Tsonis, C.G., Quigg, H., Lee, V.W.K., Leversha, L., Trounson, A.O. \& Findlay, J.K. (1983) Inhibin in individual ovine follicles in relation to diameter and atresia. J. Reprod. Fert. 67, 83-90.

Received 13 August 1985 